\title{
Analysing the Tax Structure of Turkish Economy: A Time- Varying Causality Analysis
}

\author{
Mustafa KARABACAK (https://orcid.org/0000-0001-8753-6833), Uşak University, Turkey; \\ mustafa.karabacak@usak.edu.tr
}

Oytun MEÇİK (https://orcid.org/0000-0002-7409-6266), Eskişehir Osmangazi University, Turkey; oytunm@ogu.edu.tr

\section{Türkiye Ekonomisinde Vergi Yapısının İncelenmesi: Zamanla Değişen Bir Nedensellik Analizi}

\begin{abstract}
The tax structure shows the country's choice between the principles of justice and efficiency in tax policy. In a modern economy, the tax structure is expected to change in favour of direct taxes according to the principle of justice. This article investigates the causality between tax structure and per capita GDP in Turkey using asymmetric and time-varying causality analysis. The findings reveal that the per capita GDP doesn't change the tax structure in Turkey and doesn't show any change in favour of direct taxes to ensure justice in income distribution. This situation can be evaluated as the relationship between per capita GDP, and tax structure may have been drifted apart.

Keywords

Tax Policy, Tax Structure, Turkish Economy, Asymmetric Causality Analysis, Time-Varying Causality Analysis.

JEL Classification Codes : $\mathrm{H} 21, \mathrm{H} 24, \mathrm{H} 71$.

\section{$\ddot{\mathbf{O} z}$}

Vergi yapısı, ülkenin vergi politikalarında adalet ve verimlilik ilkeleri arasındaki seçimini göstermektedir. Modern bir ekonomide vergi yapısının adalet ilkesi doğrultusunda, dolaysız vergiler lehine değişmesi beklenmektedir. Bu makale, asimetrik ve zamana göre değişen nedensellik analizi kullanarak Türkiye'deki vergi yapısı ile kişi başına düşen hasıla arasındaki nedenselliği araştırmaktadır. Bulgular, Türkiye'de kişi başına düşen hasılanın vergi yapısını değiştirmediğini ve gelir dağılımında adaleti sağlayacak şekilde, doğrudan vergiler lehine herhangi bir değişiklik göstermediğini ortaya koymaktadır. Bu durum, kişi başına düşen hasıla ile vergi yapısı arasındaki ilişkinin kopmuş olabileceği şeklinde değerlendirilebilir.
\end{abstract}

Anahtar Sözcükler $\quad$ : Vergi Politikası, Vergi Yapıs1, Türkiye Ekonomisi, Asimetrik

Nedensellik Analizi, Zamanla Değişen Nedensellik Analizi. 


\section{Introduction}

The welfare of a society depends on the macroeconomic activities in the country. Also, there are many other determinants of the welfare of society. However, taxation policy is one of the most critical determinants on the macroeconomic level. As it is known, the source of taxes is society's savings. This link makes taxes a determinant of significant macroeconomic variables and an important factor in the distribution of income in a society (Ansari, 1982: 1035). That makes tax policies a more critical issue for the economy's long run. Therefore, the government can impact economic output with its tax policies.

The taxation policy aims to support economic growth (Romer, 1990) and many other objectives such as increasing the funds required for financing public expenditure, rearranging income distribution, ensuring financial stability, affecting the allocation of resources, and preventing externalities. While applying the taxation policy, principles such as efficiency and justice come to the fore. An effective taxation policy does not mean that a fair taxation policy is used at all times. Sometimes, following the principle of economic efficiency, the focus of justice can be ignored. Ensuring economic efficiency in taxation is an important goal for every economy, but, as mentioned earlier, taxation policy is not just a policy to increase tax revenues. At the same time, it has different targets, such as ensuring economic stability and justice in income distribution. To implement a fair taxation policy, the concept of tax structure, which expresses the combinations of direct and indirect taxes in total tax revenues, gains importance. Whether the taxes are direct or indirect depends on the tax policies. However, in the theoretical framework, it is accepted that indirect taxes cause unfairness in taxation.

On the other hand, indirect taxes also negatively affect the justice of income distribution (Atkinson, 1977: 592). When examined in this context, it is seen that as the level of economic development of countries increases, the principle of justice comes to the fore in taxation. While the share of indirect tax revenues in total tax revenues is higher in underdeveloped or developing economies, direct taxes are higher in developed economies. Therefore, the high percentage of indirect tax revenues is considered an indicator of underdevelopment.

In Turkey, the taxation policies are not efficient enough. At the same time, they are not transparent. Furthermore, the tax burden in the country is not distributed fairly and concentrates on paid workers, depending on the tax structure (Siverekli-Demircan, 2003: 113; Binay, 2003: 257; Katircioglu, 2010: 105; Caliskan, 2010: 129). This fiscal inefficiency inherently causes some problems in the economy. Cause it is important to design tax policy correctly to ensure economic efficiency (Yereli \& Ata, 2011: 30). To achieve macroeconomically effective results, the fiscal policies to be followed should consider the effects of the tax structure on outputs. The length of the analysed period gains importance as this phenomenon has a long-term impact on the economy. We think that this study will contribute to the literature regarding the period it examines and the methods it uses. 
This study aims to investigate the causality relationship between direct and indirect taxes and per capita GDP in the Turkish economy by using Fourier Unit Root Test, Bootstrap Toda-Yamamoto Causality, and Symmetric Causality Analysis. This paper is organised as follows: Section 2 includes a literature review. Section 3 describes the data, methodology, and empirical findings. Finally, Section 4 presents the conclusions of the study.

\section{Literature Review}

The taxation policies of the economies are various. These policies have some effects on different macroeconomic variables in the economy. This section reviews the literature on the impact of taxes on economic variables. It is well known that there is much theoretical literature based on the Laffer curve and Supply-Side economics (Lucas, 1990). However, a literature review focuses on the relationship between taxes and GDP using similar methods.

Some of this literature can be summarised as follows: Karabacak \& Mecik (2018) use the bootstrap Toda-Yamamoto causality test developed by Hacker and Hatemi-J to examine the relationship between per capita GDP, direct and indirect taxes in the 1965-2016 period in Turkey. The study determines only one-way causality from per capita GDP to indirect taxes. However, Yildiz \& Sandalci (2019) analyses 2004-2014 in the Turkish economy. The study finds a significant two-way causality between the variables of per capita direct tax revenues, per capita indirect tax revenues, and per capita GDP. Similarly, Durkaya \& Ceylan (2006), Temiz (2008), Gocer et al. (2010), Terzi \& Yurtkuran (2016) indicate that there is two-way causality between the variables. Differently, Korkmaz et al. (2019) analyses the Turkish economy for the 2006-2018 period and find a positive and significant impact of indirect taxes on economic growth and direct taxes' adverse and powerful effects.

Acikgoz (2008) examines taxation policies and economic growth relationships in 1968-2006. The study shows a one-way causal relationship between economic growth and taxation. It is also similar to Mucuk \& Alptekin (2008) findings, which shows one-way causality from indirect taxes to economic growth in 1975-2006 for Turkey. Erdogan, Topcu \& Bahar (2013) and Arikan \& Yalcin (2013) support these findings, respectively, in 19982011 and 2004-2012.

Furthermore, according to the literature, tax revenues in Turkey are also an important factor in economic growth (Dam \& Ertekin, 2018; Akinci, 2019; Boga, 2020: 502). On the other hand, literature detects a negative relationship between tax revenues and economic growth (Idikut-Ozpence, 2017; Çiğdem \& Altaylar, 2021: 34). In addition, Ozpence \& Mercan (2020: 151) determined that the relationship between tax burden and economic growth in Turkey for the period 1970-2018 is also negative.

The relationship between tax revenues and economic growth has also been applied to different country examples in the literature. One of these is Baiardi et al. (2019), which analyses OECD countries from 1970 to 2014. The study's findings show a negative relationship between tax revenue and economic growth. Also, it compares those findings 
with Arnold et al. (2011), which analyses 21 OECD countries over the period 1971 to 2004 and shows differences in the short and long run.

As it is known, taxes have a significant impact on income distribution. There is also literature examining the effects of tax profile on income distribution for various examples. According to Hayrullahoglu \& Tuzun (2020), direct taxes' share in most OECD countries' tax systems is higher than that of indirect taxes allows an equal distribution of income as tax revenues increase. However, even though indirect taxes are against the social purpose of taxation because they focus on spending rather than earning income, according to Demirgil (2014), we can say that the increase in direct taxes in Turkey, which covers the period between 1980 and 2014, reduces the income distribution injustice, while the rise in indirect taxes increases the inequity of income distribution. Also, Balseven \& Tugcu (2017) analyses the explanatory power of taxation and transfers on income inequality in 17 developing and 30 developed countries between 1990 and 2014. The study's findings highlight that tax revenues decrease income inequalities in developing countries while social benefits decrease income inequality in developed countries.

\section{Data, Methodology and Empirical Findings}

In our study, we used per capita GDP (GDPP), the share of indirect taxes (INDIRECT), and direct taxes (DIRECT) in total tax revenues, covering the period of 19602019 in Turkey. Direct and indirect tax data was collected from the Republic of Turkey Ministry of Treasury and Finance website, and GDP per capita data was collected from OECD statistics. To test the causality between the variables, we applied the bootstrap TodaYamamoto causality test developed by Hacker and Hatemi-J (2006) and the time-varying version of the same test, the asymmetric bootstrap Toda-Yamamoto causality test developed by Hatemi-J (2012). As is known, the series must be stationary or cointegrated to apply the Granger (1988) causality test. Therefore, Granger (1988) 's method requires many pre-tests and realising multiple conditions simultaneously. Unlike the Granger causality test, based on the VAR (p) model, the Toda-Yamamoto causality test requires estimating the VAR (p $+d)$ model where $p$ is the optimal lag length for the VAR model, and $d$ is the maximum integration order of the series. So that it is insensitive to time-series properties such as stationarity and cointegration (Buyukakin et al., 2009: 111; Akcay, 2011: 84). Therefore, it does not require estimating the cointegration test and the vector error correction model. So, the Toda-Yamamoto (1995) test procedure is (equation (2)) based on the VAR(p) process in equation (1) that augmented with $\mathrm{d}$.

$$
\begin{aligned}
& y_{t}=v+A_{1} y_{t-1}+\ldots+A_{p} y_{t-p}+\mu \\
& y_{t}=\hat{v}+\hat{A}_{1} y_{t-1}+\ldots+\hat{A}_{p} y_{t-p}+\ldots+\hat{A}_{p+1} y_{t-p-d}+\hat{\mu}_{t}
\end{aligned}
$$

Equation (1) expresses a VAR model with a vector of $\mathrm{k}$ variables while $v$ a vector of constants, error terms, and a matrix of parameters. The null hypothesis of the absence of 
Granger causality is tested by applying a constraint that equates the first p parameter in equation (2) to zero. To describe Toda- Yamamoto test statistic, we can define;

$$
\begin{aligned}
& Y:\left(y_{1}, \ldots, y_{T}\right), \text { an }(n x T) \text { matrix, } \\
& \hat{D}=\left(\hat{v}, \hat{A}_{1}, \ldots, \hat{A}_{p}, \ldots, \hat{A}_{p+d}\right) \text { an }(n x(1+n(p+d))) \text { matrix, } \\
& Z_{t}=\left|\begin{array}{c}
1 \\
y_{t} \\
y_{t-1} \\
\vdots \\
y_{t-p-d+1}
\end{array}\right| \text { a }((1+n(p+d)) \mathrm{x} 1) \text { matrix, for } t=1, \ldots, T, \\
& Z=\left(Z_{0}, \ldots, Z_{T-1}\right) \text { a }((1+n(p+d)) x T) \text { matrix, and } \\
& \hat{\delta}=\left(\hat{\mu}_{1}, \ldots, \hat{\mu}_{T}\right), \text { an }(n x T) \text { matrix. }
\end{aligned}
$$

This definition lets us write a VAR $(\mathrm{p}+\mathrm{d})$ model that includes an estimated constant term $(\hat{v})$, as;

$$
Y=\hat{D} Z+\hat{\delta}
$$

The null hypothesis ( $H_{0}: C \beta=0$ ) showing the absence of Granger causality can be tested with the Wald statistic:

$$
M W A L D=(C \beta)^{\prime}\left[C\left(\left(Z^{\prime} Z\right)^{-1} \otimes S_{U}\right) C^{\prime}\right]^{-1}(C \beta)
$$

Equation (4) $\otimes$ shows the Kronecker product, and $\mathrm{C}$ is a $p \times n(1+n(p+d))$ matrix and denotes the indicator function that includes constraints. Here $\beta=$ vec $(D)$, where vec denotes the column-stacking operator. And $S_{U}=\left(\hat{\delta}_{U}^{\prime} \hat{\delta}_{U}\right) / T$ shows the variance-covariance matrix calculated for the unconstrained VAR model. Hatemi -J developed a new information criterion (HJC) ${ }^{1}$.

The Modified-Wald (MWALD) statistics have asymptotically $\chi^{2}$ distribution, as implied by Toda and Yamamoto. However, Hacker and Hatemi-J (2003) show that the MWALD statistics may over-reject the $\mathrm{H}_{0}$ due to non-normality and autoregressive

$I \quad H J C=\ln \left(\operatorname{det} \hat{\Omega}_{j}\right)+\left(\frac{n^{2} \ln T+2 n^{2} \ln (\ln T)}{2 T}\right)(j=0,1,2, \ldots, K)$. 
conditional heteroscedasticity (ARCH) effects (Gunduz \& Hatemi-J, 2005). Hacker and Hatemi-J (2003) developed a leveraged bootstrap technique to deal with these circumstances. As a first step, this study tested the causality between direct/indirect taxes and per capita GDP in the Turkish economy, applying the Leveraged Bootstrap TodaYamamoto Causality test.

As it is known, Toda-Yamamoto's (1995) methodology does not separate the effects of symmetric and asymmetric shocks. Yet, according to Hatemi-J (2012), the impact of negative shocks might be different from the positive shocks. Investors' response to negative shocks is usually more significant than positive ones. So, considering the effects of negative and positive shocks may give more information about causality between the variables. Therefore, Hatemi-J developed a causality test that considers the impact of negative and positive shocks separately based on the "hidden cointegration" idea of Granger \& Yoon (2002):

$$
y_{1 t}=y_{1 t-1}+\varepsilon_{1 t}=y_{1,0}+\sum_{i=1}^{t} \varepsilon_{1 i}
$$

and

$$
y_{2 t}=y_{2 t-1}+\varepsilon_{2 t}=y_{2,0}+\sum_{i=1}^{t} \varepsilon_{2 i}
$$

where $y_{1 t}$ and $y_{2 t}$ are both integrated random walk processes $t=1,2, \ldots T, y_{1,0}$ the constants that signify the initial values, and the white noise error terms. Definitions of positive and negative shocks are given respectively as $\varepsilon_{1 i}^{+}=\max \left(\varepsilon_{1 i}, 0\right)=\max \left(\varepsilon_{2 i}, 0\right), \varepsilon_{1 i}^{-}=\min \left(\varepsilon_{1 i}, 0\right)$ and $\varepsilon_{2 i}^{-}=\min \left(\varepsilon_{2 i}, 0\right)$. So, we can express $\varepsilon_{1 i}=\varepsilon_{1 i}^{+}+\varepsilon_{1 i}^{-}$and $\varepsilon_{2 i}=\varepsilon_{2 i}^{+}+\varepsilon_{2 i}^{-}$. By using these expressions, we can rewrite equations (5) and (6) as:

$$
\begin{aligned}
& y_{1 t}=y_{1 t-1}+\varepsilon_{1 t}=y_{1,0}+\sum_{i=1}^{t} \varepsilon_{1 i}^{+}+\sum_{i=1}^{t} \varepsilon_{1 i}^{-} \\
& y_{2 t}=y_{2 t-1}+\varepsilon_{2 t}=y_{2,0}+\sum_{i=1}^{t} \varepsilon_{2 i}^{+}+\sum_{i=1}^{t} \varepsilon_{2 i}^{-}
\end{aligned}
$$

Now we can rewrite the positive and negative shocks in cumulative form as: 


$$
y_{1 t}^{+}=\sum_{i=1}^{t} \varepsilon_{1 i}^{+}, y_{1 t}^{-}=\sum_{i=1}^{t} \varepsilon_{1 i}, y_{2 t}^{+}=\sum_{i=1}^{t} \varepsilon_{2 i}^{+} \text {and } y_{2 t}^{-}=\sum_{i=1}^{t} \varepsilon_{2 i}^{-} \text {. }
$$

As a result, allowing for only the cumulative positive shocks, we can obtain a $\operatorname{VAR}(p)$ model for the test of causality under the assumption that $\left(y_{t}^{+}=y_{1 t}^{+}, y_{2 t}^{+}\right)_{2}$ :

$$
y_{t}^{+}=v+A_{1} y_{t-1}^{+}+\ldots+A_{p} y_{t-1}^{+}+u_{t}^{+}
$$

Equation (9) $y_{t}^{+}$expresses a $2 \times 1$ vector of variables, $v$ a $2 \times 1$ vector of intercepts and $u_{t}^{+} 2 \mathrm{x} 1$ vector of error terms. Finally, $A_{r}$ it represents a $2 \times 2$ matrix consisting of parameters with lag order $r(r=1, \ldots, p)$. To see the effects of asymmetric shock, we applied Asymmetric Bootstrap Toda-Yamamoto Causality Test as a second step. However, we also used a timevarying causality test because causality may change over time.

The time-varying causality test process can be expressed as follows: Firstly, subsamples - containing equal observations - are chosen. Then the Hatemi-J (2006) causality test is applied to the subsample, which includes the first observation and the last observation (say ' $n$ ') in the first subsample. Then the first observation is excluded, and this test is applied to the second subsample between the second observation and the $(n+1)$ th observation in the second stage. The test is continued until the last observation in the data range is used by excluding the first observation at each new stage and adding a new observation to the previous observation. The test statistic obtained at each sub-sample is normalised with the bootstrap critical value to test the significance of obtained test statistics. The Wald test statistics and the critical bootstrap values change with time in this process. Hence, the test statistic obtained at each sub-sample is normalized to the $10 \%$ critical bootstrap value obtained. The values are plotted to interpret the resulting Wald test statistics. The values above the "1" line (in Graphics 1, 2, 3 and 4) show that the null hypothesis (the absence of Granger-causality) should be rejected (Yilanci \& Bozoklu, 2014).

\subsection{Bootstrap Toda-Yamamoto Causality Test}

Toda \& Yamamoto (1995) propose to use additional lag(s) in the VAR model equal to the maximum integration order of the series employed in the analysis. For this reason, generally, before applying Toda-Yamamoto (1995) causality test, the series are subjected to the unit root tests. However, Dolado \& Lutkepohl (1996) stated that adding one additional lag would be sufficient. Therefore, one additional lag will be added to the VAR model by following Dolado \& Lutkopohl's suggestion in this study. According to test results, there is

2 For the test of causality between cumulative negative shocks $\left(y_{t}^{-}=y_{1 t}^{-}, y_{2 t}^{-}\right)$vector can be used. 
no causality from per capita GDP to direct and indirect taxes. Moreover, there is also no causality from indirect/direct taxes to per capita GDP.

Table: 1

Toda-Yamamoto Causality Test Findings

\begin{tabular}{|c|c|c|c|c|}
\hline \multicolumn{5}{|c|}{ GDP per capita to Indirect Taxes } \\
\hline Lag & \multirow{2}{*}{ Test Stats. } & \multicolumn{3}{|c|}{ Critical Values } \\
\hline $\operatorname{VAR}\left(\mathrm{d}+\mathrm{k}_{\max }\right)$ & & $\% 1$ & $\% 5$ & $\% 10$ \\
\hline 3 & 0.029 & 10.884 & 6.807 & 5.086 \\
\hline \multicolumn{5}{|c|}{ GDP per capita to Direct Taxes } \\
\hline Lag & \multirow{2}{*}{ Test Stats. } & \multicolumn{3}{|c|}{ Critical Values } \\
\hline $\operatorname{VAR}\left(\mathrm{d}+\mathrm{k}_{\max }\right)$ & & $\% 1$ & $\% 5$ & $\% 10$ \\
\hline 3 & 0.037 & 10.873 & 6.782 & 5.087 \\
\hline \multicolumn{5}{|c|}{ Direct Taxes to per capita GDP } \\
\hline Lag & \multirow{2}{*}{ Test Stats. } & \multicolumn{3}{|c|}{ Critical Values } \\
\hline $\operatorname{VAR}\left(\mathrm{d}+\mathrm{k}_{\max }\right)$ & & $\% 1$ & $\% 5$ & $\% 10$ \\
\hline 3 & 2.895 & 11.924 & 7.386 & 5.479 \\
\hline \multicolumn{5}{|c|}{ Indirect Taxes to per capita GDP } \\
\hline Lag & \multirow{2}{*}{ Test Stats. } & \multicolumn{3}{|c|}{ Critical Values } \\
\hline $\operatorname{VAR}\left(\mathrm{d}+\mathrm{k}_{\max }\right)$ & & $\% 1$ & $\% 5$ & $\% 10$ \\
\hline 3 & 2.946 & 11.960 & 7.383 & 5.490 \\
\hline
\end{tabular}

These results are indeed unexpected. This is because an increase in per capita GDP, an indicator of the level of economic development, is expected to cause an increase indirect taxes and a decrease in indirect taxes. These expectations are usually met in the literature. Nevertheless, we could not detect causality from per capita GDP to direct and indirect taxes or direct and indirect taxes to per capita GDP. Therefore, these findings make the subject more interesting. Hence, we needed to examine the issue more. As mentioned earlier, the Toda-Yamamoto test does not separate between positive and negative shocks. However, generally, the effect of adverse shocks might be more significant than positive shocks. For this reason, we thought that applying an asymmetric causality test would be useful for a detailed analysis of the subject.

The results obtained from the asymmetric causality test are clear enough not to require a long explanation. Considering negative and positive shocks separately did not change the outcome either. It showed there is no causality from negative shocks to negative shocks and positive shocks to positive shocks amongst variables. More importantly, there is no causality between positive shocks in GDP per capita and positive shocks indirect taxes. It is expected that there will be a positive relationship between increases in per capita income and direct taxes. Therefore, positive shocks in GDP per capita are expected to provide information about shocks indirect taxes. However, the absence of any causal relationship between the two variables can be seen as a sign that the tax structure has not changed in favour of direct taxes despite the increases in the development level of the economy. This situation can be accepted as an indication that income is not distributed fairly, and that income distribution is realised in favour of producers and capital owners. With these exceptional results, we wanted to apply a time-varying causality test to shed light on the subject with the idea that causality can change over time. 
Table: 2

\section{Asymmetric Toda-Yamamoto Causality Test Findings}

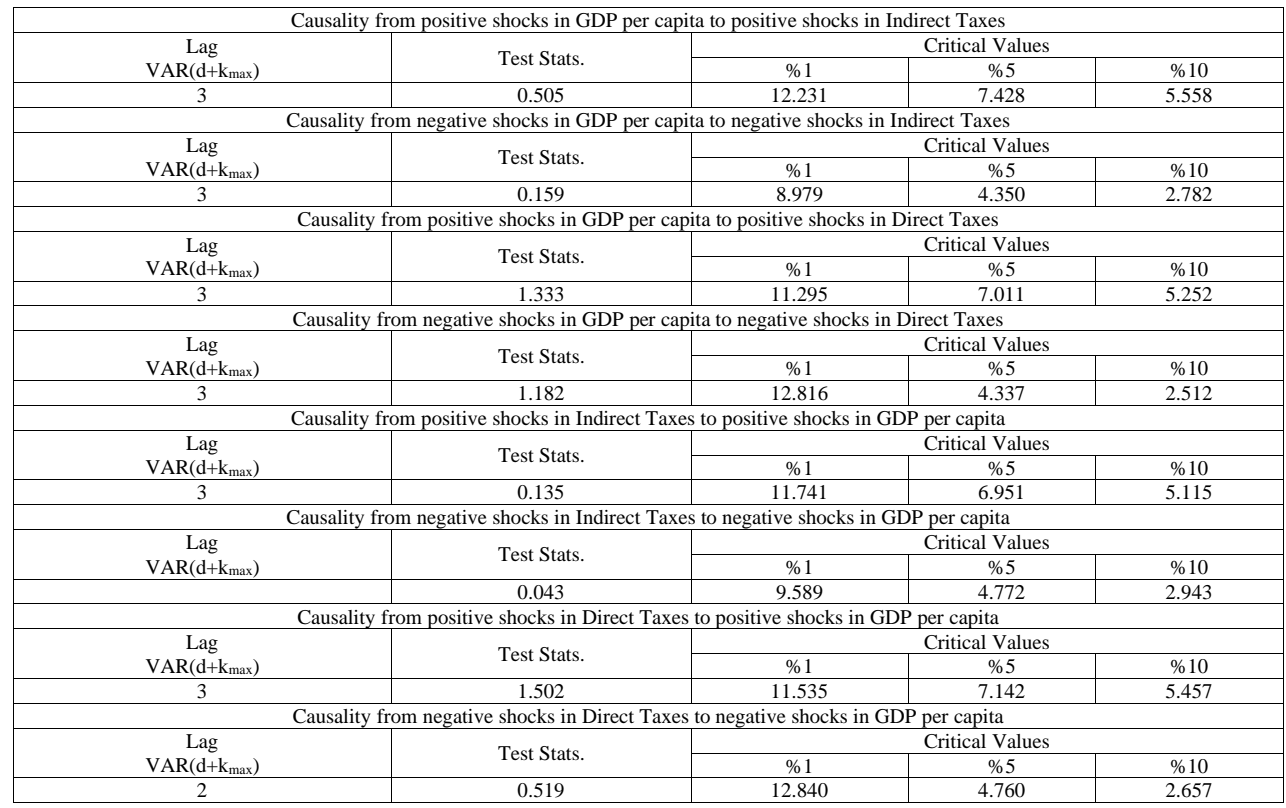

\subsection{Time-Varying Symmetric Causality Test}

Time-varying symmetric causality test results from per capita GDP to direct taxes are given in Graphic 1. As seen in Graphic 1, the W statistic calculated for 1979 is above 10\% test critical value. The $\mathrm{W}$ statistics calculated for the following periods are below the critical values until 2005. According to the test results, other periods of causality from per capita GDP to direct taxes are 2005, 2012, 2013, 2014, 2015, 2016, 2017, 2018, and 2019. There is no causality from per capita GDP to direct taxes in other periods.

In 1985, The corporate tax rate in Turkey was $46 \%$, and it was reduced to $25 \%$ in 1990. In fact, during the '90s, new regulations have been constantly introduced for Corporate Tax. However, it should be noted that these regulations, especially the tax rate reduction made in 1990, do not reflect positively on taxpayers. Because in this period, corporate earnings were also subject to income tax withholding. In addition, there may be significant differences between the regulations made in the legal tax rate and the "effective tax rate". For example, due to the implementation of "reduced corporate tax," a company investing in Turkey will hardly pay taxes on the tax base of $\$ 10$ million. Thus, while the tax structure and its consequences are analysed in Turkey, many details can be passed over (Yildirim, 2019: 91-92). 
Time-varying symmetric causality test results from per capita GDP to indirect taxes are given in Graphic 2. According to the results, the W statistic calculated for 1979 is above $10 \%$ test critical value. The $\mathrm{W}$ statistics calculated for the following periods are below the critical values until 2005. In 1979, 2005, 2006, 2012, 2013, 2014, 2015, 2016, 2017, 2018, and 2019 , there is causality from per capita GDP to indirect taxes. There is no causality from per capita GDP to direct taxes in other periods.

\section{Graphic: 1}

\section{Causality from per capita GDP to Direct Taxes}

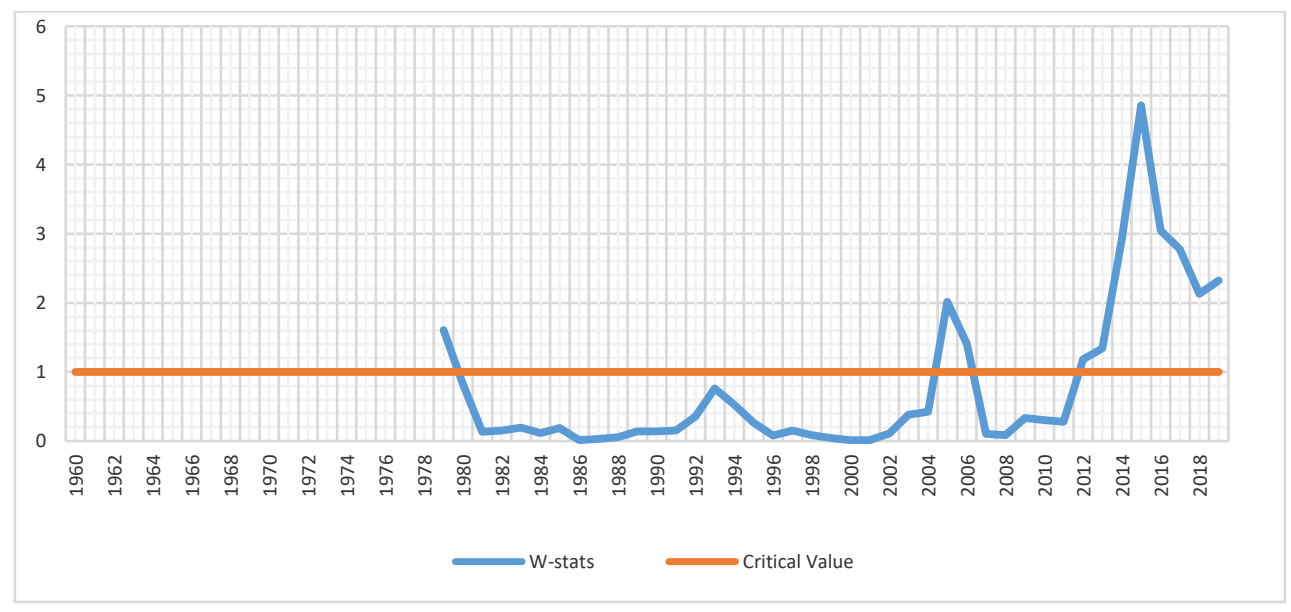

The findings indicate that at least specified years, economic development may have an indirect tax-reducing effect. However, some facts should not be overlooked at this point. Since our number of observations is insufficient, we cannot apply the time-varying asymmetric causality test. However, looking at the causality dates according to the symmetrical time-varying causality test results, we refrain from saying that the positive shocks in GDP per capita may have had an indirect tax-reducing effect as expected or instead desired. Because we know that in 2002, a new indirect tax that was not previously applied in Turkey, the Special Consumption Tax came into force. In addition, we see that in 2004, the Special Communication Tax and the Tax on Games of Chance started to be applied, and these three new tax practices are continuing. 
Graphic: 2

Causality from per capita GDP to Indirect Taxes

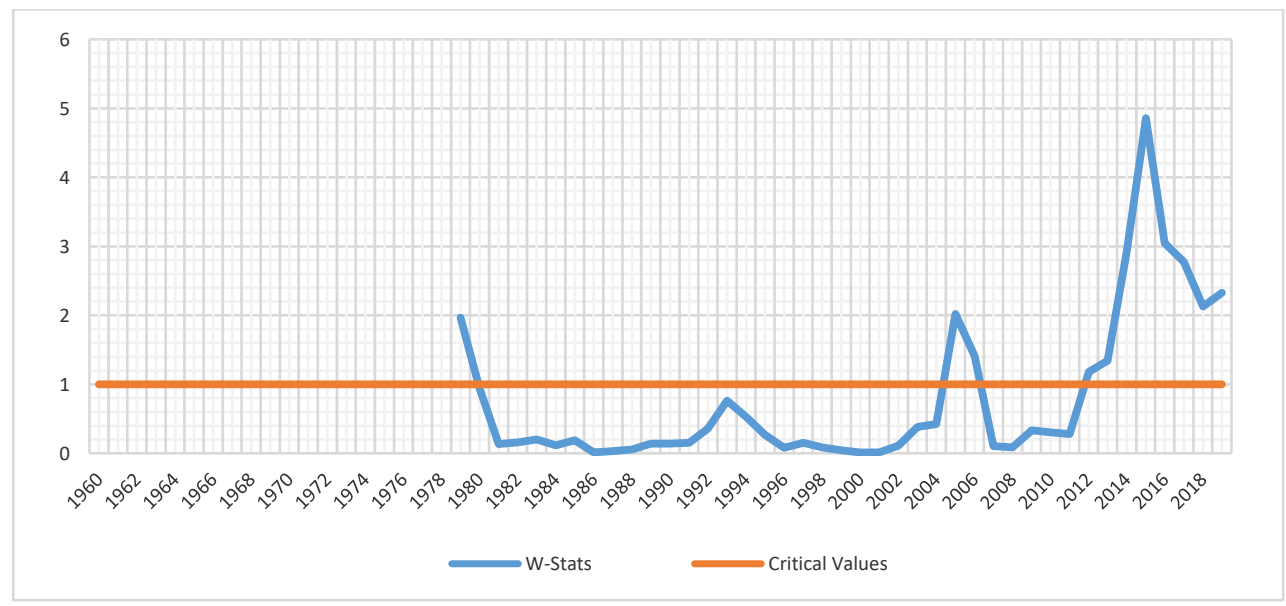

Time-varying symmetric causality test results of causality from indirect taxes to per capita GDP are given in Graphic 3. As seen in the Graphic, the W statistics calculated until 2004 are below the critical values. In this case, there is no causality relationship from indirect taxes to per capita GDP for the period before 1985-2004. The W- statistic calculated for 2004 is above $10 \%$ test critical value. In this case, there is causality from indirect taxes to per capita GDP between 1985-2004. According to the test results, other periods of causality from indirect taxes to per capita GDP is 1986-2005, 1993-2012. 


\section{Graphic: 3}

\section{Causality from Indirect Taxes to per capita GDP}

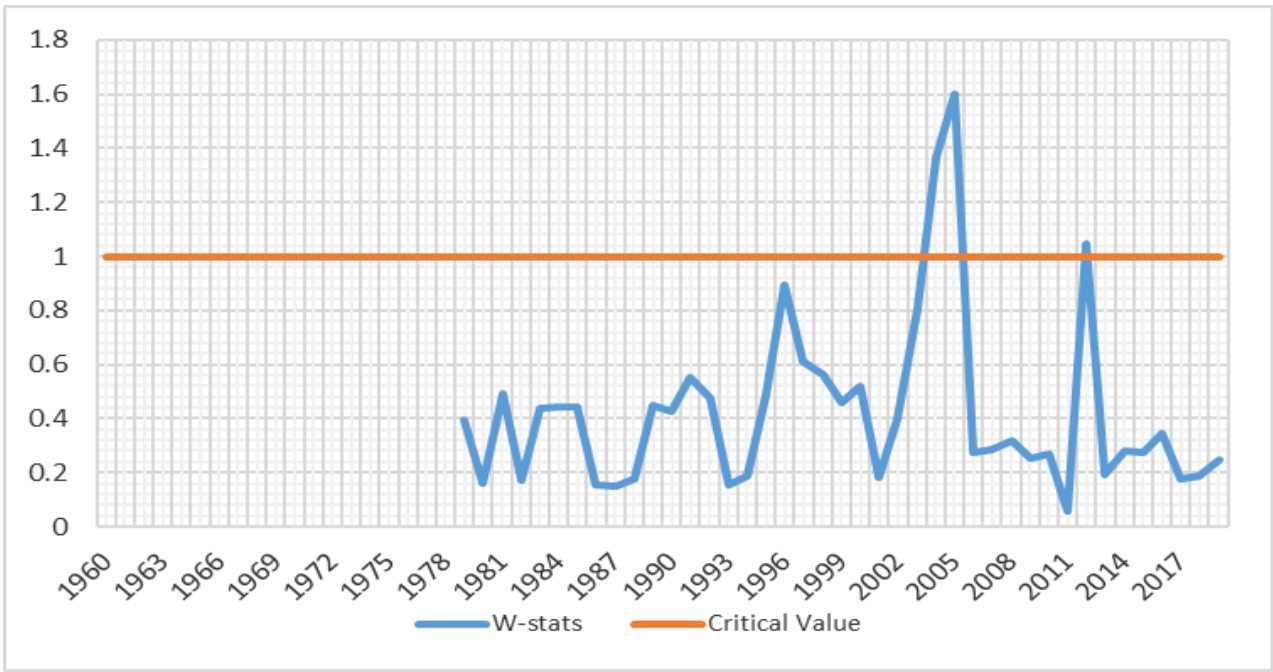

Graphic: 4

Causality from Direct Taxes to per capita GDP

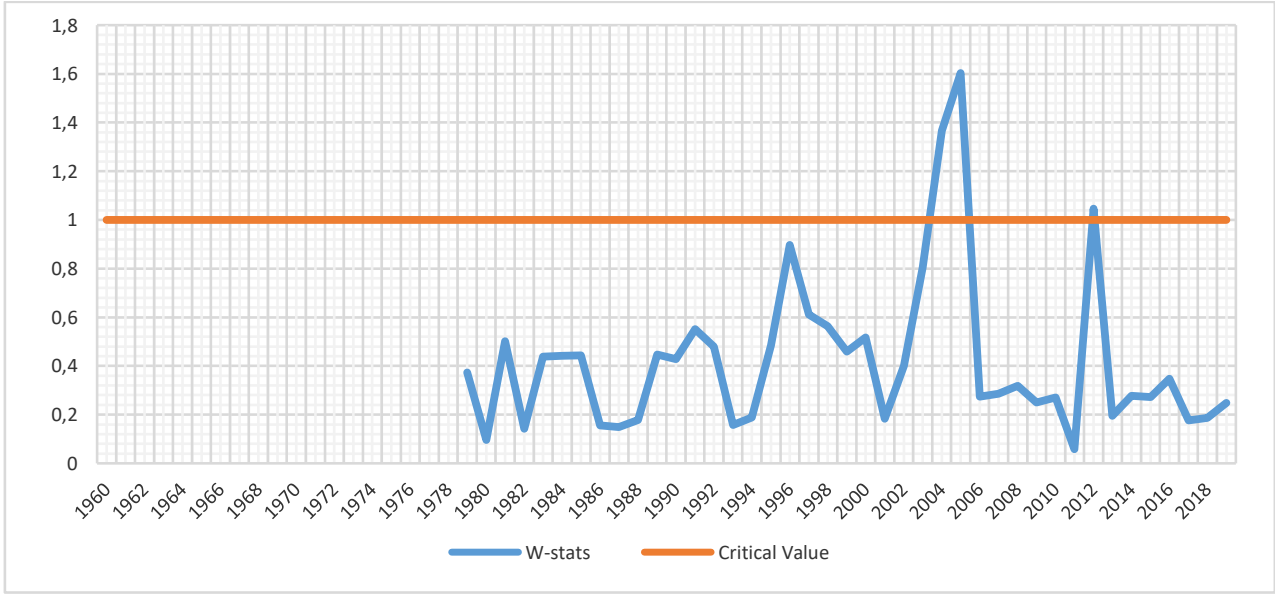

Finally, Graphic 4 shows time-varying symmetric causality test results of causality from direct taxes to per capita GDP. The Graphic indicates that the W statistics calculated until 2004 are below the critical values. For this reason, there is no causality from indirect taxes to per capita GDP before the period of 1985-2004. The W- statistic calculated for 2004 is above $10 \%$ test critical value. In this case, there is causality from indirect taxes to per 
capita GDP between 1985-2004. According to the test results, other periods of causality from indirect taxes to per capita GDP are as follows: 1986-2005, 1993-2012.

\section{Conclusion}

In this study, we investigate the causality relationship between per capita GDP and direct and indirect taxes in the Turkish economy using Bootstrap Toda-Yamamoto Causality and Asymmetric Toda-Yamamoto Causality Time-Varying Symmetric Causality Analysis. The findings show no causality amongst the variables subjected to the analysis, except for certain sub-periods. More importantly, there is no causality from per capita GDP to indirect taxes, nor is there a relationship to direct taxes. The absence of causality from per capita GDP to direct taxes can be interpreted as ignoring the principle of justice in taxation. Nevertheless, it is generally expected that the principle of efficiency will guide tax policies in such a case. Interestingly, however, the absence of causality from GDP per capita to indirect taxes can be interpreted as an indicator that the efficiency principle may also not be considered.

The causality GDP per capita to direct taxes was not observed until the sub-sample covering 1986-2005. It is observed that the relationship that existed at the beginning disappears over time, and it is observed only in certain sub-samples in the following periods. The causality was not reflected in the entire period under consideration. A similar situation is valid for GDP per capita and indirect taxes. When all these findings are analysed together, economic development does not change the tax structure in Turkey. It does not reveal any change favouring direct taxes to ensure justice in income distribution. This condition can be evaluated as the relationship between GDP per capita - an indicator of development- and tax structure may have been broken down.

These circumstances bring to mind the question of the reason for the disconnection between economic development and tax structure. Two possible explanations can be given to this question. The share of indirect taxes in Turkey is approximately $70 \%$, and this rate is around $30 \%$ in developed countries. This situation disrupts Turkey's income distribution and shows that income distribution favours capital owners and producers. It is usual to increase the share of indirect taxes in total tax revenues due to the introduction of taxes such as special consumption tax and special communication tax to close the financing gap of the public sector in times of crisis. However, these taxes are made permanent in Turkey and continue to be applied outside of crises. Moreover, their rates are increased.

The other explanation is the concept of tax competition that has increased with globalization. Increasing globalization has pushed emerging market economies that want to attract foreign direct investments and portfolio investments to their countries to lower corporate tax rates. Because, with globalization, mobilization of capital has increased, and capital has started to flee from countries where tax rates are high. Governments trying to attract foreign direct investments to their country have entered into a competition to lower 
tax rates and other facilities they provide to foreign investors. This situation even led to the emergence of tax havens.

Like other emerging market economies, Turkey has been involved in this competition and reduced corporate tax rates. The corporate tax rate of $46 \%$ in the early 90 s has been reduced to $25 \%$ today ( $23 \%$ for 2022 ). However, tax competition was not limited to lowering tax rates and continued with additional tax collection facilitation. The concept of "reduced corporate tax" mentioned earlier is one of the most important examples. Because, although the corporate tax rate appears to be $25 \%$, there has been a situation where no tax is collected for a specific investment level and tax base, thanks to the additional facilities provided to investors. As a result, countries have had to determine their tax policies according to the moves of their competitors. Therefore, the dependence of the tax policy on the policies of other countries caused the domestic purposes and principles to be ignored in tax policy practices, and the connection between this purpose and regulations and the tax policy was broken.

\section{References}

Acikgoz, S. (2008), “Türkiye'de Vergi Gelirleri, Vergi Yapısı ve İktisadi Büyüme İlişkisi: 19682006", Ekonomik Yaklaşım, 19(68), 91-113.

Akcay, S. (2011), "Causality Relationship between Total R\&D Investment and Economic Growth: Evidence from United States”, SD ̈̈ IIBF Dergisi, 16(1), 79-92.

Akinci, A. (2019), "Vergi Gelirlerinin Ekonomik Büyüme Üzerindeki Etkisi”, Finans Ekonomi ve Sosyal Araştırmalar Dergisi, 4(1), 100-106.

Ansari, M.M. (1982), "Determinants of Tax Ratio: A Cross-Country Analysis", Economic and Political Weekly, 17(25), 1035-1042.

Arikan, C. \& Y. Yalcin (2013), "Determining the Exogeneity of Tax Components with Respect to GDP", International Journal of Academic Research in Accounting, Finance and Management Sciences, 3(3), 242-255.

Arnold, J.M. et al. (2011), “Tax Policy for Economic Recovery and Growth”, The Economic Journal, 121, 59-80.

Atkinson, A.B. (1977), "Optimal Taxation and the Direct versus Indirect Tax Controversy", The Canadian Journal of Economics, 10(4), 590-606.

Baiardi, D. et al. (2019), "Tax policy and economic growth: does it really matter?", International Tax and Public Finance, 26, 282-316.

Balseven, H. \& C.T. Tugcu (2017), “Analyzing the effects of fiscal policy on income distribution: A comparison between developed and developing countries", International Journal of Economics and Financial Issues, 7(2), 377-383.

Binay, S. (2003), "Some issues in fiscal policy and central banking: The case of Turkey", BIS Papers, 20, 245-259.

Boga, S. (2020), “Türkiye'de Vergi Gelirleri ve Ekonomik Büyüme Arasındaki Asimetrik İlişki: NARDL Eşbütünleşme Yaklaşımı”, Üçüncü Sektör Sosyal Ekonomi Dergisi, 55(1), 487507. 
Buyukakin, F. vd. (2009), “Türkiye'de Parasal Aktarımın Faiz Kanalının Granger Nedensellik ve Toda-Yamamota Yöntemleri ile Analizi”, Erciyes Üniversitesi İktisadi ve İdari Bilimler Fakültesi Dergisi, 33, 101-118.

Caliskan, S. (2011), “Türkiye'de Gelir Eşitsizliği ve Yoksulluk”, Journal of Social Policy Conferences, 59, 89-132.

Cigdem, G. \& M. Altaylar (2021), "Nonlinear relationship between economic growth and tax revenue in Turkey: Hidden cointegration approach", Istanbul Journal of Economics, 71(1), 21-38.

Dam, M. \& S. Ertekin (2018), “Türkiye'de Vergi Gelirlerinin Ekonomik Büyüme Üzerindeki Etkisinin Analizi”, Vergi Raporu Dergisi, 228, 19-32.

Demirgil, B. (2018), "Vergilerin gelir dağılımı üzerindeki etkisi: Ampirik bir çalışma", Cumhuriyet Üniversitesi İktisadi ve İdari Bilimler Dergisi, 19(2), 118-131.

Dolado, J.J. \& H. Lutkepohl (1996), "Making Wald Tests Work for Cointegrated VAR Systems", Econometric Theory, 15(4), 369-386.

Durkaya, M. \& S. Ceylan (2006), "Vergi Gelirleri ve Ekonomik Büyüme”, Maliye Dergisi, 150, 7989.

Erdogan, E. vd. (2013), "Vergi Gelirleri ve Ekonomik Büyüme İlişkisi: Türkiye Ekonomisi Üzerine Eşbütünleşme ve Nedensellik Analizi”, Finans Politik \& Ekonomik Yorumlar, 50 (576), 99-109.

Gocer, I. vd. (2010), "Ekonomik Büyüme ile Vergi Gelirleri Arasındaki İlişki: Sınır Testi Yaklaşımı”, Dumlupınar Üniversitesi Sosyal Bilimler Dergisi, (28), 97-110.

Granger, C.W.J. \& G. Yoon (2002), "Hidden Cointegration”, Department of Economics Working Paper University of California, No: 2002-02.

Granger, C.W.J. (1988), "Some Recent Developments in the Concept of Causality”, Journal of Econometrics, 39, 199-211.

Gunduz, L. \& A. Hatemi-J (2005), “Is the tourism-led growth hypothesis valid for Turkey?", Applied Economics Letters, (12), 499-504.

Hacker, R.S. \& A. Hatemi-J (2003), "Tests for causality between integrated variables based on asymptotic and bootstrap distribution", Working Paper 2003:02, Department of Statistics, Lund University, Sweden.

Hacker, R.S. \& A. Hatemi-J (2006), "Tests for causality between integrated variables using asymptotic and bootstrap distributions: theory and application", Applied Economics, 38(13), 1489-1500.

Hatemi-J, A. (2012), “Asymmetric causality tests with an application”, Empirical Economics, (43), 447-456.

Hayrullahoglu, B. \& O. Tuzun (2020), “The Effect of Taxes on Income Distribution: An Analysis for Turkey and Other Selected OECD Countries", Journal of Economics, Business \& Organization Research, Proceedings of the Third EBOR Conference 2020, 413-426.

Idikut-Ozpence, A. (2017), “Türkiye'de 1980 Sonrası Kamu Harcamaları, Vergi Gelirleri ve Ekonomik Büyüme Arasındaki İlişkinin Analizi”, Pamukkale Üniversitesi Sosyal Bilimler Enstitüsü Dergisi, (28), 31-41. 
Karabacak, M. \& O. Mecik (2018), The Effectiveness of Tax Policies in Turkey: Causality Analysis, <https://lisbon2018.econworld.org/papers/Karabacak_Mecik_TheEffectiveness.pdf>, 19.09.2020.

Katircioglu, S.T. (2010), "Is There a Long-Run Relationship between Taxation and Growth: The Case of Turkey", Romanian Journal of Economic Forecasting, 13(1), 99-106.

Korkmaz, S. et al. (2019), "The impact of direct and indirect taxes on the growth of the Turkish economy", Public Sector Economics, 43(3), 311-323.

Lucas, R.E. (1990), “Supply-Side Economics: An Analytical Review”, Oxford Economic Papers, 42, 293-316.

Mucuk, M. \& V. Alptekin (2008), “Türkiye'de Vergi ve Ekonomik Büyüme İlişkisi: VAR Analizi (1975-2006)", Maliye Dergisi, (155), 159-174.

Ozpence, O. \& N. Mercan (2020), "The relationship between tax burden and economic growth: Turkey case", Journal of Business, Economics and Finance, 9(2), 143-154.

Romer, P.M. (1990), "Endogenous Technological Change”, The Journal of Political Economy, 98(5), 71-102.

Siverekli-Demircan, E. (2003), "Vergilendirmenin Ekonomik Büyüme ve Kalkınmaya Etkisi", Erciyes Üniversitesi İktisadi ve İdari Bilimler Fakültesi Dergisi, 21, 97-116.

Temiz, D. (2008), Türkiye'de Vergi Gelirleri ve Ekonomik Büyüme İlişkisi: 1960-2006 Dönemi, <http://debis.deu.edu.tr/userweb/iibf_kongre/dosyalar/temiz.pdf〉, 23.10.2020.

Terzi, H. \& S. Yurtkuran (2016), “Türkiye'de Dolaylı/Dolaysız Vergi Gelirleri ve GSYH İlişkisi”, Maliye Dergisi, (171), 19-33.

Toda, H.Y. \& Y. Yamamoto (1995), "Statistical inference in vector autoregressions with possibly integrated processes", Econometrics, (66), 225-250.

Yereli, A.B. \& A.Y. Ata (2011), "Vergi adaletine ulaşma yöntemleri çerçevesinde fayda ilkesinin teorik açıdan değerlendirilmesi”, Maliye Dergisi, 161, 21-32.

Yilanci, V. \& S. Bozoklu (2014), “Türk sermaye piyasasında fiyat ve işlem hacmi ilişkisi: zamanla değişen asimetrik nedensellik analizi”, Ege Akademik Bakış, 14(2), 211-220.

Yilanci, V. et al. (2020), "Testing the Unemployment Hysteresis in G7 Countries: A Fresh Evidence from Fourier Threshold Unit Root Test", Romanian Journal of Economic Forecasting, XXIII (3), 49-59.

Yildirim, A.H. (2019), "Vergi Rekabeti ve Türkiye'de Kurumlar Vergisi Üzerine Etkisi”, Yüksek Lisans Tezi, Marmara Üniversitesi: İstanbul.

Yildiz, F. \& U. Sandalci (2019), "Vergi Yapısı ve Ekonomik Büyüme Arasındaki Nedensellik İlişkisi: Türkiye'de İller Düzeyinde Ampirik Bir Analiz (2004-2014)”, Vergi Dünyası, 38(452), 20-34. 